\title{
The effects of short-term rainfall variability on leaf isotopic traits of desert plants in sand-binding ecosystems
}

\author{
Liangju Zhao ${ }^{a}$, Lixin Wang ${ }^{b *}$, Honglang Xiao ${ }^{a}$, Xiaohong Liuc, Guodong Cheng ${ }^{\mathrm{d}}$, Yunfeng Ruan
}

a. Heihe Key Laboratory of Ecohydrology and River Basin Science, Cold and Arid Regions Environmental and Engineering Research Institute, Chinese Academy of Sciences, Lanzhou 730000, China;

b. Department of Earth Sciences, Indiana University-Purdue University, Indianapolis (IUPUI), Indianapolis, Indiana 46202, USA;

c. State Key Laboratory of Cryospheric Sciences, Cold and Arid Regions Environmental and Engineering Research Institute, Chinese Academy of Sciences, Lanzhou 730000, China;

d. State Key Laboratory of Frozen Soil Engineering, Cold and Arid Regions Environmental and Engineering Research Institute, Chinese Academy of Sciences, Lanzhou 730000, China.

\section{Running title: Leaf isotopic traits of sand-binding plants}

Author for Correspondence

Lixin Wang

Department of Earth Sciences

Indiana University-Purdue University, Indianapolis (IUPUI)

Indianapolis, Indiana 46202, USA

Office phone number: 317-274-7764

Office fax: 317-274-7699

E-mail: w.lixin@gmail.com

This is the author's manuscript of the article published in final edited form as:

Zhao, L., Wang, L., Xiao, H., Liu, X., Cheng, G., \& Ruan, Y. (2013). The effects of short-term rainfall variability on leaf isotopic traits of desert plants in sand-binding ecosystems. Ecological Engineering, 60, 116-125. http://dx.doi.org/ 10.1016/j.ecoleng.2013.07.022 


\begin{abstract}
Sand-binding vegetation is effective in stabilizing sand dunes and reducing soil erosion, thus helps minimize the detrimental effects of desertification. The aim of this study is to better understand the relationships between water and nutrient usage of sand-binding species, and the effects of succession and rainfall variability on plants' water-nutrient interactions. We examined the effects of long-term succession (50 years), inter-annual rainfall variability (from $65 \%$ of the mean annual precipitation in 2004 to $42 \%$ in 2005) and seasonality on water-nutrient interactions of three major sand-binding species (Artemisia ordosica, Hedysarum scoparium and Caragana korshinskii) by measuring foliar $\delta^{13} \mathrm{C}, \delta^{15} \mathrm{~N}$ and $[\mathrm{N}]$. Long-term succession in general did not significantly alter $\delta^{13} \mathrm{C}, \delta^{15} \mathrm{~N}$ and $[\mathrm{N}]$ of the three species. Short-term rainfall variability, however, significantly increased foliar $\delta^{13} \mathrm{C}$ levels of all three species by 1.0 to $1.8 \%$ o during the severely dry year. No significant seasonal patterns were found in foliar $\delta^{13} \mathrm{C}$ and $\delta^{15} \mathrm{~N}$ values of the three species, whereas foliar [N] varied by season. For the two leguminous shrubs, the correlations between $\delta^{13} \mathrm{C}$ and $\delta^{15} \mathrm{~N}$ were positive in both sampling years, and the positive correlation between [N] and $\delta^{13} \mathrm{C}$ was only found in the severely dry year. The results indicate that these sand-binding plants have developed into a relatively stable stage and they are able to regulate their nitrogen and water use in responding to environmental conditions, which reinforces the effectiveness of plantation of native shrubs without irrigation in degraded areas. However, the results also indicate that short-term climate variability could have severe impact on the vegetation functions.
\end{abstract}

Key words: desertification, drought, isotope, nitrogen, sand-binding, Tengger Desert 


\section{Introduction}

Desertification is one of the major environmental problems worldwide (Reynolds et al., 2007) and it occurs in almost every habitable region such as North America (e.g., Schlesinger et al., 1990; Li et al., 2008; Ravi et al., 2009), Africa (e.g., Thomas et al., 2008; Wang et al., 2010a) and northern China (e.g., Chen et al., 1996; Mitchell et al., 1998, Liu et al., 2012). The deserts in northern China are expanding at an estimated rate of $2100 \mathrm{~km}^{2}$.year-1 (Chen et al., 1996; Mitchell et al., 1998).

Revegetation of native shrubs, a massive ecological engineering project (Mitsch et al., 1993), has been one of the most effective methods to reduce desertification. Large areas of China's desert regions have been reclaimed through planting of native plants since the 1950s (Shapotou Desert Research and Experiment Station, 1986). For example, the 1000-km long Baotou-Lanzhou railway that passes through Shapotou region has been protected by sand-binding shrubs that were planted in 1956, 1964, 1981 and 1987, respectively (Shapotou Desert Research and Experiment Station, 1986). The success of these efforts suggests that it is an effective approach to control desertification and to restore the ecological environment along transportation corridors in the desert regions of China (Xiao et al., 2003a; Li et al., 2006). Many revegetated species, such as Caragana intermedia, Calligonum arborescens and Tamarix ramosissima, disappeared over the years, whereas some native species such as Artemisia ordosica, Hedysarum scoparium and Caragana korshinskii survived during succession and have become the dominant shrubs (Ma et al., 2002). As a result of long-term succession, the planted vegetation ecosystem is expected to develop into a stable system 
(Xiao et al., 2003b). The effects of long-term succession and short-term climate variability (e.g., rainfall) on the function of these successful sand-binding species (e.g., A. ordosica, $H$. scoparium, and C. korshinskii) are not yet fully understood, which hinders our ability to predict future successional pathways of such planted ecosystems under the circumstances of potential warming and drought in this region (Solomon et al., 2007).

In this study, we measured dual isotope $\left({ }^{13} \mathrm{C}\right.$ and $\left.{ }^{15} \mathrm{~N}\right)$ compositions and nitrogen concentrations $([\mathrm{N}])$ of three dominant species, i.e., A. ordosica, H. scoparium, and $C$. korshinskii, and analyzed their interactions to investigate the effects of long-term succession (50 years) and short-term drought (2 years) on plant uptake of water and nitrogen at a desert stabilized by sand-binding plants in northern China. Besides providing valuable isotopic information of these sand-binding species, this study will have both theoretical and applied importance in the restoration of degraded ecosystems and in improving our ability to predict the response of planted sand-binding vegetation to climate change.

Stable isotopes are used in the investigation because they provide integrated information on plant water and nutrient use and serve as powerful tracers in ecosystem studies. The stable carbon isotope ratio $\left(\delta^{13} \mathrm{C}\right)$ of plant tissues reflects the relations between plant carbon and soil water. The effect of water availability on carbon isotope discrimination during photosynthesis of $C_{3}$ plant is relatively well understood (e.g., Farquhar et al., 1982). For example, photosynthesis depends on water availability, and low water availability can decrease the assimilation of carbon, thereby reducing plant productivity and the corresponding nitrogen requirements or assimilation rates, leading to different patterns of $\delta^{13} \mathrm{C}$ and $\delta^{15} \mathrm{~N}$ variation (Yoneyama et al., 2001). Foliar $\delta^{13} \mathrm{C}$ typically increases when water availability is low, as a 
result of stomatal closure and reduced transpiration (Peuke et al., 2006). And foliar $\delta^{13} \mathrm{C}$ is higher in the water-limited treatment relative to the well-watered treatment (Grant et al., 2012). Analyses of $\delta^{13} \mathrm{C}$ have greatly increased our understanding of the relationships between water and carbon use by desert plants (Ehleringer, 1993). Nitrogen isotope ratio $\left(\delta^{15} \mathrm{~N}\right)$ provides information on ecosystem nitrogen cycling (Högberg et al., 1995; Roggy et al., 1999; Ometto et al., 2006; Bai et al., 2009) and plant nitrogen isotope discrimination is related to the availability of nutrients and water (Högberg, 1997; Swap et al., 2004; Aranibar et al., 2008; Wang et al., 2010b). Previous studies showed that succession affected N cycling and it was reflected in foliar $\delta^{15} \mathrm{~N}$ (Davidson et al., 2007; Wang et al., 2007), and foliar $\delta^{15} \mathrm{~N}$ signatures decreased as successional age increased at both the plant community and species levels (Wang et al., 2007).

Plant $\delta^{13} \mathrm{C}$ and $\delta^{15} \mathrm{~N}$ signatures are often regulated by two or more factors (BassiriRad et al., 2003; Murphy and Bowman, 2009). For example, Schulze et al. (1991) point out that the significant correlation between $\delta^{15} \mathrm{~N}$ and $\delta^{13} \mathrm{C}$ values of nitrogen-fixing African trees is caused by decreased water use efficiency, compared with that of the non-nitrogen-fixers. The decreased water use efficiency in nitrogen fixer usually is a result of the extra cost of carbohydrate supply to the nitrogen-fixing diazotroph (Farquhar and Richards, 1984).

Previous research also shows that photosynthetic capacity is strongly correlated with $\mathrm{C}_{3}$ plant foliar [N] because photosynthetic enzymes, such as RuBP carboxylase, contain large amounts of nitrogen (Reich et al., 1998; Tognetti and Penuelas, 2003). It is also found that higher photosynthetic activity leads to enriched foliar $\delta^{13} \mathrm{C}$ values (O'Leary, 1981). Because of these two reasons, positive correlations between foliar $\delta^{13} \mathrm{C}$ and $[\mathrm{N}]$ have been found in 
many cases (e.g., Sparks and Ehleringer, 1997; Wang et al., 2008). Such relationships together with the positive correlation between foliar $\delta^{15} \mathrm{~N}$ and [N] in non-nitrogen-fixing plants (Hobbie et al., 2000; Wang et al., 2007) suggest that foliar $\delta^{13} \mathrm{C}, \delta^{15} \mathrm{~N}$, and [N] levels are closely linked.

This study is to investigate the interactions of plant nitrogen and water use in planted sand-binding vegetation after long-term succession and to test whether there are functional group (potential nitrogen-fixer and non nitrogen-fixer) dependent adaptation strategies to water and nitrogen variations in the harsh environments. Specifically, the objectives of this study are to investigate (1) the long-term effect (up to 50 years) of successional age on the isotopic signatures $\left(\delta^{13} \mathrm{C}\right.$ and $\left.\delta^{15} \mathrm{~N}\right)$ and $[\mathrm{N}]$ of three dominant shrubs in planted sand-binding vegetation communities; (2) the effects of seasonality and short-term drought on variations in isotopic signatures and [N] of each species; and (3) the relationships between $\delta^{13} \mathrm{C}, \delta^{15} \mathrm{~N}$, and [N] of the three shrub species. The results will provide important implications on how plant species adapt to harsh environments in terms of water use efficiency and nutrient use during succession and how plant species respond to environmental changes.

\section{Materials and Methods}

\subsection{Study area}

Shapotou region is located at the southeastern border of the Tengger Desert in China (Figure 1). The region receives high solar radiation and is low in relative humidity. Average annual precipitation is $180.2 \mathrm{~mm}$, with $80 \%$ of the rainfall occurring from May to September. The mean annual temperature is $10.0^{\circ} \mathrm{C}$, with a mean January temperature of $-6.9^{\circ} \mathrm{C}$ and a mean July temperature of $24.3^{\circ} \mathrm{C}$. The water table is more than $80 \mathrm{~m}$ below ground, thus 
rainfall is usually the only source of water for plants.

The planting of sand-fixing vegetation in the mobile dunes of the Shapotou region began in 1956 and subsequent revegetation occurred in 1964, 1981 and 1987, respectively. There was no irrigation or fertilization for these plantings. We calculated the successional age as of the year 2005 (the final year of the sampling), and the four sites selected were $50 \mathrm{yr}$-old, 42 yr-old, 25 yr-old and 19 yr-old for 1956, 1964, 1981 and 1987 planting, respectively. As a result of long-term succession, the mobile dunes were already stabilized at the time of the experiment. Local ecosystems have changed into a grass dominated semi-desert landscape with increasing rates of biological processes and an accumulation of soil organic matter despite the extreme environment (Table 1) (Xiao et al., 2003b). In all planted zones, the three dominant species survived long-term succession were $A$. ordosica, $H$. scoparium and $C$. korshinskii. A. ordosica is a succulent, non-nitrogen-fixing semi-shrub xerophyte, and is found in desert and semi-desert biomes. H. scoparium and C. korshinskii are leguminous xerophytic shrubs and have been reported to have nitrogen fixing activities (Tan et al., 1996; Ma, 2003). The soil physical and chemical properties also improved after revegetation (Table 1) though levels of variation remained high. The vegetated soil profile in the area were composed of a surface biological crust (up to $13.0 \mathrm{~mm}$ thick), a transitional layer (up to 50 mm thick) and an original layer of shifting sand (Duan et al., 2003). The biological crust may supply most of the fixed nitrogen to desert plant and soil communities. It may also reduce the loss of nutrient-rich fine soil particles to erosion by binding soil particles together, promoting the formation and increasing the size of soil aggregates.

\subsection{Plant sampling}


The field sampling took place at the Shapotou Desert Experimental Research Station $\left(37^{\circ} 27.55^{\prime} \mathrm{N}, 105^{\circ} 00.64^{\prime} \mathrm{E}\right)$, which is located on the southeastern border of the Tengger Desert. The field sampling was conducted at successional sites of 50 yr-old, 42 yr-old, 24 yr-old and 19 yr-old (Figure 1). At each successional site, we established eight (four for the $19 \mathrm{yr}$-old site due to its low vegetation coverage) $5 \mathrm{~m} \times 5 \mathrm{~m}$ plots including different microhabitats such as windward slope, ridge and hollow. Each plot had five to six individuals of $A$. ordosica shrubs and two to three individuals of $C$. korshinskii and $H$. scoparium shrubs, with similar heights and canopy dimensions for each species. At the selected sites, we sampled the mature leaves of A. ordosica, C. korshinskii, and H. scoparium at a monthly interval from the beginning of the growing season in April (except mid-May was used in 2004) to the end of the growing season in September according to the growth seasonality. Specifically, in 2004, the mature leaves were sampled on May 13, May 28, June 30, July 28, August 28 and September 23; and in 2005, the mature leaves were sampled on April 23, May 28, June 27, July 27, August 27, and September 29, respectively. Each time, 20 leaves or assimilating shoots of each species from each plot were collected between 8 and 10 a.m. All the leaf samples were fully developed and current-year leaves. For each successional age, samples from the same plot were pooled for each species.

\subsection{Climatic conditions}

The De Martonne's (1926) aridity index (AI), AI = P / $(\mathrm{T}+10)$, was used to indicate the long-term and short-term climate conditions, where $\mathrm{P}$ was precipitation in $\mathrm{mm}$ and $\mathrm{T}$ was temperature in degree C. The mean AI from 1950 to 1988 was 9.2, which indicated that the climate was dry (i.e., AI < 10.0). The climate was dry during the 2004 growing season (AI = 
3.9, $65 \%$ of the long-term mean precipitation) and was extremely dry during the 2005 growing season $(\mathrm{AI}=2.2,42 \%$ of the long-term mean precipitation). Climate conditions of our sites during 2004 and 2005 growing seasons were summarized in Table 2.

\subsection{Leaf trait analyses}

The sampled leaves were wiped carefully with deionized water, and then oven-dried $\left(70^{\circ} \mathrm{C}, 48 \mathrm{~h}\right)$ and homogenized into a fine powder in a ball mill (Pulverisette 23, Fritsch, Idar-Oberstein, Germany). A 2000-3000 $\mu \mathrm{g}$ sub-sample of the plant tissues was used for the $\delta^{15} \mathrm{~N}$ analysis and a $100-200 \mu$ g sub-sample was used for the $\delta^{13} \mathrm{C}$ analysis. Foliar $\delta^{15} \mathrm{~N}$ and $\delta^{13} \mathrm{C}$ values were determined using an elemental analyzer (EA 3000, Euro Vector, Milan, Italy) coupled to a continuous-flow isotope mass spectrometer (Isoprime, Micromass Ltd., Manchester, UK) at Heihe Key Laboratory of Ecohydrology and River Basin Science, Cold and Arid Regions Environmental and Engineering Research Institute. The standard deviations of repeated measurements using working standards (USGS 24 for $\delta^{13} \mathrm{C}$ and IAEA-No-3 for $\delta^{15} \mathrm{~N}$ ) were $\pm 0.2 \%$ or for $\delta^{15} \mathrm{~N}$ and $\pm 0.1 \%$ for $\delta^{13} \mathrm{C}$. All $\delta^{13} \mathrm{C}$ and $\delta^{15} \mathrm{~N}$ values were reported based on the international standards ( $V-P D B$ for $\delta^{13} \mathrm{C}$ and atmospheric nitrogen for $\left.\delta^{15} \mathrm{~N}\right)$. $\delta^{15} \mathrm{~N}$ and $\delta^{13} \mathrm{C}=\left[\left(\mathrm{R}_{\text {sample }} / \mathrm{R}_{\text {standard }}\right)-1\right]$, where $\mathrm{R}$ was the molar ratio $\left({ }^{15} \mathrm{~N}:{ }^{14} \mathrm{~N}\right.$ or ${ }^{13} \mathrm{C}:{ }^{12} \mathrm{C}$, respectively). The dried samples were ground in a stainless steel mill, and wet-digested in concentrated $\mathrm{H}_{2} \mathrm{SO}_{4}$ to determine total $\mathrm{N}$ ( $\mathrm{Li}$ et al., 2010). The [N] was measured using semi-micro Kjeldahl analysis (Bremner and Mulvaney, 1982).

\subsection{Statistical analysis}

The effects of successional age, sampling year and seasonality on leaf $\delta^{15} \mathrm{~N}, \delta^{13} \mathrm{C}$ and [N] were tested using three-way nested analysis of variance (ANOVA) for each species, with 
seasonality nested within sampling year. If there were significant interactions, differences in foliar $\delta^{15} \mathrm{~N}, \delta^{13} \mathrm{C}$ and $[\mathrm{N}]$ would be compared using two-way ANOVA with successional age and sampling year, or sampling year and seasonality as main factors. If the results of two-way ANOVA were significant, the differences in foliar $\delta^{15} \mathrm{~N}, \delta^{13} \mathrm{C}$ and $[\mathrm{N}]$ among species would be compared using one-way ANOVA. The Tukey's honestly significant difference (HSD) post hoc test was used to separate the means. For each species, correlations were conducted between foliar $\delta^{15} \mathrm{~N}, \delta^{13} \mathrm{C}$, and [N]. All analyses were performed using Statistica (StatSoft, Inc., Tulsa, OK).

\section{Results}

\subsection{Foliar $\delta^{15} \mathrm{~N}, \delta^{13} \mathrm{C}$, and [N] of each species}

Foliar $\delta^{15} \mathrm{~N}$ values of A. ordosica, H. scoparium, and C. korshinskii differed significantly ( $\mathrm{p}<0.05)$, with the most negative value in A. ordosica $(-3.1 \pm 0.1 \%$ o (mean $\pm \mathrm{SE})$ ) and the most positive value in $C$. korshinskii $(-1.5 \pm 0.1 \%$ ) (Table 3$)$. Foliar $\delta^{13} \mathrm{C}$ values of $A$. ordosica (-24.4 $\pm 0.1 \%$ o) and H. scoparium (-24.5 $\pm 0.1 \%$ o) did not show significant difference, but both values were significantly more negative than that of $C$. korshinskii $(-23.2 \pm 0.1 \%$, $\mathrm{p}<$ 0.05) (Table 3). Foliar [N] of C. korshinskii (16.1 $\left.\pm 0.98 \mathrm{~g} \mathrm{~kg}^{-1}\right)$ was significantly lower than those of A. ordosica (24.2 $\left.\pm 0.36 \mathrm{~g} \mathrm{~kg}^{-1}\right)$ and H. scoparium (22.7 $\left.\pm 0.43 \mathrm{~g} \mathrm{~kg}^{-1}\right)$, which did not differ significantly from each other (Table 3).

\subsection{Effects of successional age}

There were no significant changes in foliar $\delta^{13} \mathrm{C}$ values of all three species along succession except for a higher (less negative) foliar $\delta^{13} \mathrm{C}$ value of $H$. scoparium at the 25 yr-old site compared to the other successional sites. There were no significant changes in 
foliar $\delta^{15} \mathrm{~N}$ values and [N] of both leguminous shrubs (H. scoparium and C. korshinskii) along succession ( $p>0.05$, Fig. 2). The $\delta^{15} \mathrm{~N}$ value of $A$. ordosica was the highest at the $50 \mathrm{yr}$-old site in 2004, which was in accordance with the higher foliar [N] at the same period (Fig. 2). The $\delta^{15} \mathrm{~N}$ value of $A$. ordosica was also higher at the 19 yr-old site in 2005.

\subsection{Effects of short-term rainfall variations}

In 2004, foliar $\delta^{13} \mathrm{C}$ values of all three species were remarkably lower than those in 2005, which was an extremely dry year ( $\mathrm{p}<0.05$, Table 4$)$. Mean foliar $\delta^{15} \mathrm{~N}$ values did not differ significantly between the two years for all three species (Table 4). The foliar [N] of $C$. korshinskii was significantly lower $\left(9.8 \pm 0.6 \mathrm{~g} \mathrm{~kg}^{-1}\right)$ in the extremely dry year than in the dry year $\left(23.6 \pm 0.5 \mathrm{~g} \mathrm{~kg}^{-1}, \mathrm{p}<0.05\right)$, but foliar $[\mathrm{N}]$ of the other species did not differ significantly between the two years (Table 4).

\subsection{Effects of seasonality}

Foliar $\delta^{15} \mathrm{~N}$ of the three species did not differ seasonally in either year (Fig. 3a, d, and g). With the exception of early May, the seasonal differences in foliar $\delta^{13} \mathrm{C}$ of the three species were also not significant (Fig. 3b, 3e, and 3h). The effects of seasonality on foliar [N] varied for different species and year combination. In the arid year of 2004, the highest foliar [N] levels of A. ordosica were found in mid May, August and September, and the lowest levels were found at the end of July. In the extremely arid year of 2005, foliar [N] of A. ordosica was relatively stable before July, with the highest [N] in August and September (Fig. 3c). For $H$. scoparium and C. korshinskii, the foliar [N] levels differed significantly by season in both years, and the seasonal patterns were similar. The $[\mathrm{N}]$ was the highest at the beginning of the growing season, decreased gradually until the end of the growing season, and then remained 
relatively constant until late August (Fig. 3f, 3i).

\subsection{Relationships between foliar $\delta^{15} \mathrm{~N}, \delta^{13} \mathrm{C}$, and [N]}

Table 5 presents the correlations between foliar $\delta^{15} \mathrm{~N}, \delta^{13} \mathrm{C}$ and $[\mathrm{N}]$ of all three species in both sampling years. In both years, the correlations between foliar $\delta^{15} \mathrm{~N}$ and $\delta^{13} \mathrm{C}$ of $A$. ordosica were not significant. Foliar $\delta^{15} \mathrm{~N}$ was significantly correlated with $\delta^{13} \mathrm{C}$ of both leguminous shrubs $(H$. scoparium and $C$. korshinskii) in both years $(\mathrm{p}<0.01)$. The correlations in C. korshinskii ( $r=0.74$ in 2004 and 0.77 in 2005) were stronger than those in H. scoparium ( $\mathrm{r}=0.31$ in 2004 and 0.38 in 2005). Foliar [N] of A. ordosica was significantly positively correlated with $\delta^{15} \mathrm{~N}$ in both years $(r=0.41$ in 2004 and 0.28 in 2005, $\mathrm{p}<0.01)$. Foliar $\delta^{13} \mathrm{C}$ and $[\mathrm{N}]$ of $H$. scoparium and $C$. korshinskii were only positively correlated in the extremely arid year $(\mathrm{r}=0.39$ for $H$. scoparium and 0.49 for $C$. korshinskii, $\mathrm{p}<0.01)$.

\section{Discussion}

\subsection{Variations in three plant species}

Foliar $\delta^{13} \mathrm{C}$ is an indicator of long-term plant water use efficiency (Farquhar et al., 1989). Our results showed that the $\delta^{13} \mathrm{C}$ values (ranging from -21.1 to $-26.6 \%$ ) of the dominant shrubs in the Tengger Desert (a cold desert) were more positive than the values reported for other desert C3 plants, which ranged from -21.0 to $-28.0 \%$ in the northern Namaqualand Desert of South Africa (Rundel et al., 1999), from -22.0 to $-29.0 \%$ in the Arizona deserts of the United States (Ehleringer and Cooper, 1988) and from -24.8 to $-30.2 \%$ in the Kalahari, southern Africa (Wang et al., 2010b).

The three shrubs differed significantly in $\delta^{15} \mathrm{~N}$ values (Table 3), with C. korshinskii being significantly less negative (-1.5\%o), and A. ordosica being more negative (-3.1\%o). The 
$\delta^{15} \mathrm{~N}$ values of nitrogen-fixing plants have been shown to approximate atmospheric $\delta^{15} \mathrm{~N}$ value (0\%) (Shearer and Kohl, 1986; Dawson et al., 2002). Less negative $\delta^{15} \mathrm{~N}$ values (close to 0\%o) of $C$. korshinskii suggest that its main nitrogen source is the fixation of atmospheric nitrogen. C. korshinskii and $H$. scoparium are both leguminous shrubs, but the $\delta^{15} \mathrm{~N}$ values of $H$. scoparium were significantly lower (-2.7\%o) (Table 3), which indicates that its nitrogen-fixing activity is low or it uses alternative nitrogen sources. Golluscio et al. (2006) reported that some leguminous shrubs with the presence of nodules did not appear to be actively fixing nitrogen in arid ecosystems, but nitrogen fixation can occur in some favorable years. Similar observations are reported for southern African ecosystems where foliar $\delta^{15} \mathrm{~N}$ values of some leguminous Acacia trees reach 8\%o (Wang et al., 2010b), indicating minimum nitrogen fixing activities in normal years (vs. wet years). Because atmospheric nitrogen tends to have more negative $\delta^{15} \mathrm{~N}$ values, more negative $\delta^{15} \mathrm{~N}$ values in $A$. ordosica suggest that this shrub may obtain a large amount of its nitrogen from precipitation and deposition (Skinner et al., 2004).

\subsection{Effect of successional age on leaf isotopic characteristics}

The relatively constant foliar $[\mathrm{N}]$ and $\delta^{13} \mathrm{C}$ values of the three species along succession indicate that these plant species are able to regulate their nitrogen and water use in response to environmental conditions from as early as $19 \mathrm{yr}$ after succession (the youngest successional stage in this study). The stable nitrogen uptake and assimilation along succession are further supported by the constant foliar $\delta^{15} \mathrm{~N}$ values of both leguminous shrubs (H. scoparium and $C$. korshinskii). In addition to the isotope data, soil water capacity data also provide support for a stable stage after $19 \mathrm{yr}$ of succession (Figure 4). It clearly showed that there was a significant decrease in soil water capacity until 19 years and after that the soil water capacity became 
stable. This provides a strong and alternative evidence for the conclusion of stable succession after 19 years. There was no clear decreasing trend in foliar $\delta^{15} \mathrm{~N}$ during succession as found in secondary successional ecosystems under a temperate climate (Wang et al., 2007), indicating that the openness (e.g., the ratio between external loss and internal cycling) of the ecosystem nitrogen cycle does not change along the succession. For A. ordosica, there was higher foliar $\delta^{15} \mathrm{~N}$ value at the $50 \mathrm{yr}$-old site in 2004, which is linked to higher soil [N] (Table 2) and foliar [N] (Fig. 2) at this successional age. The higher foliar $\delta^{15} \mathrm{~N}$ value at the 19 yr-old site in 2005 is unexpected and the cause is inconclusive, but probably related to local conditions (e.g., microhabitat).

\subsection{Effect of interannual rainfall and seasonality on leaf isotopic characteristics}

A large body of literature has reported negative correlations between plants $\delta^{13} \mathrm{C}$ values and the availability of water (e.g., precipitation) (Miller et al., 2001; Van de Water et al., 2002; Swap et al., 2004; Murphy and Bowman, 2009; Wang et al., 2010b). In our study, foliar $\delta^{13} \mathrm{C}$ values of the three shrubs in the extremely arid year of 2005 (61.3 mm precipitation during the growing season) were significantly more positive than those in the arid year of 2004 (107.1 mm precipitation during the growing season). This may be resulted from decreased stomatal and mesophyll conductance under extremely arid conditions, which in turn increased water use efficiency (e.g., Choi et al., 2005). The difference in the $\delta^{13} \mathrm{C}$ values of $C$. korshinskii between years was $1.8 \%$, which was greater than those of $A$. ordosica (1.0\%o) and H. scoparium (1.1\%) (Table 4). Higher foliar $\delta^{13} \mathrm{C}$ value of C. korshinskii and its higher sensitivity to rainfall variation indicate that $C$. korshinskii is more sensitive to water availability than the other two species. Overall, with the exception of $H$. scoparium in 2005, 
there was no significant variation in $\delta^{13} \mathrm{C}$ of the three shrubs during the growing season (Fig. 3b, 3e, 3h). This suggests that seasonal differences in this dry and hot environment have a relatively minor effect on the photosynthetic capacity and stomatal conductance of these species.

Foliar $\delta^{15} \mathrm{~N}$ values did not vary much between the dry and the extremely dry year (Fig. 3). These two years were different in rainfall (116.2 $\mathrm{mm}$ in 2004 and $74.9 \mathrm{~mm}$ in 2005). The constant annual foliar $\delta^{15} \mathrm{~N}$ values suggest that water availability does not play an important role in nitrogen cycles and/or plant uptake in these two years. This conclusion is different from many earlier studies which demonstrate strong rainfall/soil moisture controls on soil nitrogen cycle in water-limited systems (e.g., Wang et al., 2009). The likely reason for this discrepancy is that both years were drought years (65\% of the mean annual precipitation in 2004 and 42\% in 2005), and the effect of soil moisture on nitrogen cycle (e.g., plant uptake) diminished significantly. The relatively constant seasonal patterns in $\delta^{15} \mathrm{~N}$ in both years support the basic assumptions that seasonality does not affect plant foliar $\delta^{15} \mathrm{~N}$ (Garten, 1993; Swap et al., 2004; Ometto et al., 2006).

Many studies have shown that a large proportion of the foliar nitrogen is incorporated into photosynthesis-related enzymes (Evans, 1989), and the leaves with higher leaf nitrogen concentrations have higher photosynthetic rates (Field and Mooney, 1986). The foliar [N] of A. ordosica and $H$. scoparium didn't change between the dry and extreme dry years, indicating either nitrogen is not limiting or water limitation effect suppresses nitrogen effect for these two species. The foliar [N] of C. korshinskii was significantly lower than in 2004 and was significantly lower than foliar [N] of the other two species (Fig. 3c, 3f and 3i, Table 
4). The lower foliar $[\mathrm{N}]$ of $C$. korshinskii during the extremely dry year may be related to less active nitrogen fixation and assimilation, indicating the $C$. korshinskii nitrogen uptake is less sensitive to water availability than other two species and only the extreme arid year affects its nitrogen uptake. Under such conditions, high energy cost of nitrogen fixation limits the potential of nitrogen fixation in natural ecosystems when photosynthesis decreases under water stress (Vitousek and Howarth, 1991). The seasonal patterns of foliar [N] of all three species varied remarkably during the growing season (Fig. 3c, 3f, and 3i). Foliar [N] of A. ordosica decreased from May to July reaching approximately the initial level. The decreasing trend is probably due to the dilution effects which resulted from low nitrogen assimilation capacity under drought and high temperature as growing season develops. Foliar [N] of $H$. scoparium and C. korshinskii decreased throughout the growing season, probably resulting from the decreased nitrogen-fixing activity.

\subsection{Relationships of leaf characteristics}

Foliar $\delta^{15} \mathrm{~N}$ and $\delta^{13} \mathrm{C}$ values are often correlated through their links with the growth and nutrition of plants, and with carbon and nitrogen mineralization processes (e.g., Perroni-Venture et al., 2009). The correlations between $\delta^{13} \mathrm{C}$ and $\delta^{15} \mathrm{~N}$ of the two leguminous shrubs (H. scoparium and C. korshinskii) were significant and positive in both years (Table 5). These results suggest that carbon and nitrogen isotope discrimination of these plants are regulated by similar factors and that carbon and nitrogen cycling are connected.

Foliar $\delta^{13} \mathrm{C}$ is affected by both internal factors (e.g., foliar [N]) and external factors (e.g., water availability). Sparks and Ehleringer (1997) suggest that the increase in $\delta^{13} \mathrm{C}$ value with increasing foliar $[\mathrm{N}]$ reflects a positive effect of high nitrogen availability on photosynthetic 
rate. Many other studies have reported that nitrogen fertilization tends to increase $\delta^{13} \mathrm{C}$ by lowering the internal to ambient $\mathrm{CO}_{2}$ concentration ratio $\left(\mathrm{C}_{\mathrm{i}} / \mathrm{C}_{\mathrm{a}}\right)$ mainly through enhanced carboxylation efficiency (Hogberg and Alexander, 1995; Livingston et al., 1999; Choi et al., 2005). This phenomenon is particularly obvious for seedlings or natural stands where nitrogen is the primary limiting factor (Hogberg and Alexander, 1995; Livingston et al., 1999; Choi et al., 2005). In our study, positive correlation between $[\mathrm{N}]$ and $\delta^{13} \mathrm{C}$ was only found in $C$. korshinskii and H. scoparium in the extremely arid year $(r=0.49$ and 0.39 , respectively, Table 5). It is possible that the two leguminous shrubs reduce nitrogen-fixing activity during the extremely arid year and nitrogen starts to limit the photosynthetic rates. This is particularly evident for C. korshinskii as its foliar [N] was much lower in the extremely arid year (Table 4). Lower photosynthetic capacity causes more discrimination against ${ }^{13} \mathrm{C}$ and results in lower $\delta^{13} \mathrm{C}$. At the same time, foliar $\delta^{13} \mathrm{C}$ was higher in the extremely dry year for all three species (Table 4), contradicting the foliar [N] effect since lower foliar [N] supposedly results in lower $\delta^{13} \mathrm{C}$ values. The higher foliar $\delta^{13} \mathrm{C}$ in the extremely dry year corroborates with the water effect on foliar $\delta^{13} \mathrm{C}$, indicating that water availability is the predominant factor in this system and the water effect suppresses the nitrogen effect.

There were significant positive relationships between $\delta^{15} \mathrm{~N}$ and $[\mathrm{N}]$ of $A$. ordosica. This pattern has been widely reported for non-nitrogen-fixing plants (Vitousek et al., 1989; Garten and Van Miegroet, 1994; Johannisson and Högberg, 1994; Högberg et al., 1995; Hobbie et al., 2000; Wang et al., 2007). Hobbie et al. (2000) suggest that the positive correlations reflect the changes in the proportion of nitrogen obtained through mycorrhizae. The mycorrhizae association status of the studied shrubs was not certain, but presumably the association was 
weak. We think that the variation in soil nitrogen availability (e.g., Table 2) is the major cause of the observed correlations between $\delta^{15} \mathrm{~N}$ and [N], which is similar to what happens during secondary succession in northern Virginia (Wang et al., 2007).

\section{Summary}

To better understand the long-term succession and short-term climate variability effects on the functions of three major sand-binding species (A. ordosica, H. scoparium and $C$. korshinskii), we examined the effects of succession, rainfall variability, and seasonality on foliar $\delta^{13} \mathrm{C}, \delta^{15} \mathrm{~N}$ and $[\mathrm{N}]$. The study has both theoretical and applied importance in the restoration of degraded lands and in improving our ability to predict the response of planted sand-binding vegetation to climate change. The results showed that,

1) Long-term succession did not significantly alter $\delta^{13} \mathrm{C}, \delta^{15} \mathrm{~N}$ and [N] levels of the three species in general. The study indicates that these sand-binding ecosystems have developed into a stable stage. The relatively constant foliar $\delta^{13} \mathrm{C}, \delta^{15} \mathrm{~N}$ and [N] levels of the three species along succession indicate that these species are able to regulate their nitrogen and water use in response to environmental conditions.

2) Short-term rainfall variability, however, significantly increased foliar $\delta^{13} \mathrm{C}$ of all three species by 1.0 to $1.8 \%$, indicating higher water use efficiency during a more severe drought. The results indicate that short-term drought significantly affects the plant functions.

3) No significant seasonal patterns were found in foliar $\delta^{13} \mathrm{C}$ and $\delta^{15} \mathrm{~N}$ of the three species. However, foliar [N] levels varied by season and differed between leguminous and non-leguminous species. 
4) The correlations between $\delta^{13} \mathrm{C}$ and $\delta^{15} \mathrm{~N}$ were significant and positive for two leguminous shrubs (H. scoparium and C. korshinskii) in both years. A positive correlation between $[\mathrm{N}]$ and $\delta^{13} \mathrm{C}$ was found in both species only in the extremely arid year. These results suggest that carbon and nitrogen isotope discrimination in these leguminous plants are controlled by similar factors and leguminous shrubs might be limited by soil nitrogen during the extremely dry year.

5) There are functional type (leguminous shrubs vs. non-leguminous shrubs) dependent adaptation strategies to the extreme environments. Interestingly, the functions of $H$. scoparium, a leguminous shrub share similarities with both leguminous $C$. korshinskii and non-leguminous A. ordosica. For example, in terms of its water and nitrogen use responses to inter-annual rainfall variability, $H$. scoparium is similar to A. ordosica indicated by their similar responses in foliar $\delta^{13} \mathrm{C}$ and foliar [N]. In terms of its nitrogen and water relationship within a growing season, $H$. scoparium is similar to C. korshinskii indicated by similar foliar $\delta^{13} \mathrm{C}-[\mathrm{N}]$ and foliar $\delta^{13} \mathrm{C}-\delta^{15} \mathrm{~N}$ relationships of these two species.

\section{Acknowledgments}

This research was supported by the National Natural Science Foundation of China (91125025, 91025016), the National Science \& Technology Pillar Program during the Twelfth Five-Year Plan Period (2011BAC07B05), and the Ministry of Forestry Welfare Special Project (201004010-05). 


\section{References}

Aranibar, J.N., Anderson, I.C., Epstein, H.E., Feral, C.J.W., Swap, R.J., Ramontsho, J., Macko, S.A., 2008. Nitrogen isotope composition of soils, $C_{3}$ and $C_{4}$ plants along land use gradients in southern Africa. Journal of Arid Environments 72, 326-337 doi:310.1016/j.jaridenv.2007.1006.1007.

Bai, E., Boutton, T.W., Liu, F., Wu, X.B., Archer, S.R., Hallmark, C.T., 2009. Spatial variation of the stable nitrogen isotope ratio of woody plants along a topoedaphic gradient in a subtropical savanna. Oecologia 159, 493-503, DOI: 410.1007/s00442-00008-01246-00440.

BassiriRad, H., Constable, J., Lussenhop, J., Kimball, B., Norby, R., Oecchel, W., Reich, P., Schlesinger, W., Zitzer, S., Sehtiya, H., Silim, S., 2003. Widespread foliage $\delta^{15} \mathrm{~N}$ depletion under elevated $\mathrm{CO}_{2}$ : inferences for the nitrogen cycle. Global Change Biology 9, 1582-1590.

Bremner, J., Mulvaney, C., 1982. Nitrogen-total. In: A. Page, R. Mille and D. Keeney (Eds), Methods of Soil Analysis, Part 2. Agronomy, Vol. 9, Soil Science Sciety of America Madison, pp. 595-624.

Chen, G., Dong, Z., Yan, P., 1996. Desertification: international research topics and research strategies of China. Exploration of Nature 15, 1-5.

Choi, W.J., Chang, S.X., Allen, H.L., Kelting, D.L., Roe, H.M., 2005. Irrigation and fertilization effects on foliar and soil carbon and nitrogen isotope ratios in a loblolly pine stand. Forest Ecology and Management 213, 90-101.

Davidson, E.A., Carvalho, C.J.R.d., Figueira, A.M., Ishida, F.Y., Ometto, J.P.H.B., Nardoto, G.B., Sabá, R.T., Hayashi, S.N., Leal, E.C., Vieira, I.C.G., Martinelli, L.A., 2007. Recuperation of nitrogen cycling in Amazonian forests following agricultural abandonment. 
Nature 447, 995-998.

Dawson, T.E., Mambelli, S., Plamboeck, A.H., Templer, P.H., Tu, K.P., 2002. Stable isotope in plant ecology. Annu. Rev. Ecol. Syst. 33, 507-559.

De Martonne, E., 1926. Une nouvelle fonction climatologique: L’indice d'aridité. La Meteorologie, 449-458.

Duan, Z., Wang, G., Xiao, H., Dong, Z., 2003. Abiotic soil crust formation on dunes in an extremely arid environment: a 43-year sequential study. Arid Land Res Manage 17, 43-54.

Ehleringer, J., 1993. Carbon and water relations in desert plants: an isotopic perspective. In: J. Ehleringer, A. Hall and G. Farquhar (Eds), Stable Isotopes and Plant-Water Relations, Academic Press, San Diego, pp. 155-172.

Ehleringer, J., Cooper, T., 1988. Correlations between carbon isotope ratio and microhabitat in desert plants. Oecologia 76, 562-566.

Evans, J., 1989. Photosynthesis and nitrogen relationships in leaves of $\mathrm{C}_{3}$ plants. Oecologia 78, 9-19.

Farquhar, G., Ehleringer, J., Hubick, K., 1989. Carbon isotope discrimination and photosynthesis. Ann. Rev. Plant Physiol. Mol. Biol. 40, 503-537.

Farquhar, G., Richards, R., 1984. Isotopic composition of plant carbon correlated with water use efficiency of wheat genotypes. Austral J of Plant Physiol 11, 539-552.

Farquhar, G.D., O'Leary, M.H., Berry, J.A., 1982. On the relationship between carbon isotope discrimination and the intercellular carbon dioxide concentration in leaves. Australian Journal of Plant Physiology 9, 121-137.

Field, C., Mooney, H., 1986. The photosynthesis-nitrogen relationship in wild plants. In: T. 
Givnish (Ed), On the Economy of Plant Form and Function, Cambridge, Cambridge University Press, pp. 25-55.

Garten, C., Van Miegroet, H., 1994. Relationships between soil nitrogen dynamics and natural

${ }^{15} \mathrm{~N}$ abundance in plant foliage from Great Smoky Mountains National Park. Can J For Res 24, 1636-1645.

Garten, C.T., 1993. Variation in foliar ${ }^{15} \mathrm{~N}$ abundance and the availability of soil nitrogen on walker branch watershed $\quad$ Ecology 74, 2098-2113.

Grant, O.M., Davies, M.J., James, C.M., Johnson, A.W., Leinonen, I., Simpson, D.W., 2012. Thermal imaging and carbon isotope composition indicate variation amongst strawberry (Fragaria ananassa) cultivars in stomatal conductance and water use efficiency. Environmental and Experimental Botany 76, 7-15

Golluscio, R., Faigón, A., Tanke, M., 2006. Spatial distribution of roots and nodules, and $\delta^{15} \mathrm{~N}$ evidence of nitrogen fixation in Adesmia volckmanni, a Patagonian leguminous shrub. Journal of Arid Environments 67, 328-335.

Hobbie, E.A., Macko, S.A., Williams, M., 2000. Correlations between foliar $\delta^{15} \mathrm{~N}$ and nitrogen concentrations may indicate plant-mycorrhizal interactions. Oecologia 122, 273-283. Högberg, P., 1997. ${ }^{15} \mathrm{~N}$ natural abundance in soil-plant systems New Phytologist 137, 179-203.

Hogberg, P., Alexander, I., 1995. Role of root symbioses in African woodland and forest: evidence from ${ }^{15} \mathrm{~N}$ abundance and foliar analysis. Journal of Ecology 83, 217-224.

Högberg, P., Johannisson, C., Högberg, M., Högbom, L., Näsholm, T., Hällgren, J., 1995. Measurements of abundances of ${ }^{15} \mathrm{~N}$ and ${ }^{13} \mathrm{C}$ as tool in retrospective studies of $\mathrm{N}$ balances and 
water stress in forests: a discussion of preliminary results. Plant Soil 168, 125-133.

Johannisson, C., Högberg, P., 1994. ${ }^{15} \mathrm{~N}$ abundance of soils and plants along an experimentally induced forest nitrogen supply gradient. Oecologia 97, 322-325.

Li, J., Okin, G., Alvarez, L., Epstein, H., 2008. Effects of wind erosion on the spatial heterogeneity of soil nutrients in two desert grassland communities. Biogeochemistry 88, 73-88.

Li, J., Richter, D.d., Mendoza, A., Heine, P., 2010. Effects of land-use history on soil spatial heterogeneity of macro- and trace elements in the Southern Piedmont USA. Geoderma 156, 60-73.

Li, X., Xiao, H., He, M., Zhang, J., 2006. Sand barriers of straw checkerboards for habitat restoration in extremely arid desert regions. Ecological Engineering 28, 149-157.

Li, X.-R., Xiao, H.-L., Zhang, J.-G., Wang, X.-P., 2004. Long-term ecosystem effects of sand-binding vegetation in the Tengger Desert, northern China. Restoration Ecology 12, 376-390.

Liu, B., Liu, Z., Wang, L., 2012. The colonization of active sand dunes by rhizomatous plants through vegetative propagation and its role in vegetation restoration. Ecological Engineering 44, 344-347.

Livingston, N., Guy, R., Sun, Z., Ethier, G., 1999. The effects of nitrogen stress on the stable carbon isotope composition, productivity and water use efficiency of white spruce (Picea glauca (Moench) Voss) seedlings. Plant Cell and Environment 22, 281-289.

Ma, F., 2003. Study on the stability of Shapotou artificial sand-fixing vegetation Vol. PhD, Cold and Arid Regions Environmental and Engineering Research Institute, Chinese Academy 
of Sciences, Lanzhou.

Ma, F., Li, X., Long, L., Zhang, J., 2002. Population structure and regeneration of planted Artemisia ordocisa in Shapotou. Journal of Desert Research 22, 571-575.

Miller, J., Williams, R., Farquhar, G., 2001. Carbon isotope discrimination by a sequence of Eucalyptus species along a subcontinental rainfall gradient in Australia. Functional Ecology, $222-232$.

Mitsch, W.J., Yan, J., Cronk, J.K., 1993. Ecological engineering-contrasting experiences in China with the West. Ecological Engineering 2, 177-191.

Mitchell, D., Fullen, M., Trueman, I., Fearnehough, W., 1998. Sustainability of reclaimed desertified land in Ningxia, China. Journal of Arid Environments 39, 239-251.

Murphy, B., Bowman, D., 2009. The carbon and nitrogen isotope composition of Australian grasses in relation to climate. Functional Ecology 23, 1040-1049, doi: 1010.1111/j.1365-2435.2009.01567.x.

O'Leary, M.H., 1981. Carbon isotope fractionation in plants. Phytochemistry $\quad$ 20, 553-567. Ometto, J., Ehleringer, J., Domingues, T., Berry, J., Ishida, F., Mazzi, E., Higuchi, N., Flanagan, L., Nardoto, G., Martinelli, L., 2006. The stable carbon and nitrogen isotopic composition of vegetation in tropical forests of the Amazon Basin, Brazil. Biogeochemistry 79, 251-274.

Peuke, A.D., Gessler, A., Rennenberg, H., 2006. The effect of drought on C and N stable isotopes in different fractions of leaves, stems and roots of sensitive and tolerant beech ecotypes. Plant, Cell and Environment 29, 823-835.

Perroni-Venture, Y., Montana, C., Garcia-Oliva, F., 2009. Carbon-nitrogen interactions in 
fertility island soil from a tropical semi-arid ecosystem. Functional Ecology 24, 233-242, doi: 210.1111/j.1365-2435.2009.01610.x.

Ravi, S., D’Odorico, P., Wang, L., White, C.S., Okin, G.S., Macko, S.A., Collins, S.L., 2009. Post-fire resource redistribution in desert grasslands: a possible negative feedback on land degradation. Ecosystems 12, 434-444.

Reich, P., Ellsworth, D., Walters, M., 1998. Leaf structure (specific leaf area) modulates photosynthesis-nitrogen relations: evidence from within and across species and functional groups. Functional Ecology 12, 948-958.

Reynolds, J., Smith, D.S., Lambin, E., Turner, B., Mortimore, M., Batterbury, S., Downing, T., Dowlatabadi, H., Fernández, R., Herrick, J., Huber-Sannwald, E., Leemans, R., Lynam, T., Maestre, F., Ayarza, M., Walker, B., 2007. Global desertification: building a science for dryland development. Science 316, 847-851.

Roggy, J., Prévost, M., Gourbiere, F., Casabianca, H., Garbaye, J., Domenach, A., 1999. Leaf natural ${ }^{15} \mathrm{~N}$ abundance and total $\mathrm{N}$ concentration as potential indicators of plant $\mathrm{N}$ nutrition in legumes and pioneer species in a rain forest of French Guiana. Oecologia 120.

Rundel, P., Esler, K., Cowling, R., 1999. Ecological and phylogenetic patterns of carbon isotope discrimination in the winter-rain-fall flora of the Richterveld, South Africa. Plant Ecology 142, 133-148.

Schlesinger, W.H., Reynolds, J.E., Cunningham, G.L., Huenneke, L.E., Jarrell, W.M., Virginia, R.A., Whitford, W.G., 1990. Biological feedbacks in global desertification. Science 247, 1043-1048.

Schulze, E.-D., Gebauer, G., Ziegler, H., Lange, O.L., 1991. Estimates of nitrogen fixation by 
trees on an aridity gradient in Namibia. Oecologia 88, 451-455.

Shapotou Desert Research and Experiment Station, C.A.o.S., 1986. The principles and measures taken to stabilize shifting sands along the railway line in the south eastern edge of the Tengger Desert. J Desert Res 6, 1-19.

Shearer, G., Kohl, D., 1986. $\mathrm{N}_{2}$-fixation in field settings: estimations based on natural ${ }^{15} \mathrm{~N}$ abundance. Austral J Plant Physiol 13, 699-756.

Skinner, R., Ineson, P., Hicks, W., Jones, H., Sleep, D., Leith, I., Sheppard, L., 2004. Correlating the spatial distribution of atmospheric ammonia with $\delta^{15} \mathrm{~N}$ values at an Ammonia release site. Water Air and Soil Pollution 4, 219-228.

Solomon, S., Qin, D., Manning, M., Chen, Z., Marquis, M., Averyt, K., Tignor, M., Miller, H., 2007. IPCC, 2007: Climate Change 2007: The Physical Science Basis. Contribution of Working Group I to the Fourth Assessment Report of the Intergovernmental Panel on Climate Change. Cambridge University Press, Cambridge and New York, 996 pp.

Sparks, J., Ehleringer, J., 1997. Leaf carbon isotope discrimination and nitrogen content for riparian trees along elevational transects. Oecologia 109, 362-367

Swap, R.J., Aranibar, J.N., Dowty, P.R., Gilhooly, W.P., Macko, S.A., 2004. Natural abundance of ${ }^{13} \mathrm{C}$ and ${ }^{15} \mathrm{~N}$ in $\mathrm{C}_{3}$ and $\mathrm{C}_{4}$ vegetation of southern Africa: patterns and implications. Global Change Biology 10, 350-358.

Tan, Z.Y., Zhu, M., He, X., Li, Y., 1996. Investigation of rhizobium of leguminous plants in Shanxi province and some areas of Gansu province and Ningxia autonomous region. Acta Botanica Boreali-Occidentalia Sinica 15 189-196.

Thomas, A.D., Hoon, S.R., Linton, P.E., 2008. Carbon dioxide fluxes from cyanobacteria 
crusted soils in the Kalahari. Applied Soil Ecology 39, 254-263.

Tognetti, R., Penuelas, J., 2003. Nitrogen and carbon concentrations, and stable isotope ratios in Mediterranean shrubs growing in the proximity of a $\mathrm{CO}_{2}$ spring. Biologia Plantarum 46, 411-418.

Van de Water, P., Leavitt, S., Betancourt, J., 2002. Leaf $\delta^{13} \mathrm{C}$ variability with elevation, slope aspect, and precipitation in the southwest United States. Oecologia 132, 332-343.

Vitousek, P., Shearer, G., Kohl, D., 1989. Foliar ${ }^{15} \mathrm{~N}$ natural abundance in Hawaiian rainforest: patterns and possible mechanisms. Oecologia 78, 383-388.

Vitousek, P.M., Howarth, R.W., 1991. Nitrogen limitation on land and in the sea: How can it occur? Biogeochemistry 13, 87-115.

Wang, L., Shaner, P.-J.L., Macko, S., 2007. Foliar $\delta^{15} \mathrm{~N}$ patterns along successional gradients at plant community and species levels. Geophysical Research Letters 34, L16403.

Wang, L., B. Kgope, P. D’ Odorico, S. Macko, 2008. Carbon and nitrogen parasitism by a xylem - tapping mistletoe (Tapinanthus oleifolius) along the Kalahari Transect: a stable isotope study. African Journal of Ecology 46, 540-546.

Wang, L., D'Odorico, P., Manzoni, S., Porporato, A., Macko, S., 2009. Carbon and nitrogen dynamics in southern African savannas: the effect of vegetation-induced patch-scale heterogeneities and large scale rainfall gradients. Climatic Change 94, 63-76.

Wang, L., D’Odorico, P., Ries, L., Caylor, K., Macko, S., 2010a. Combined effects of soil moisture and nitrogen availability variations on grass productivity in African savannas. Plant and Soil 328, 95-108, 110.1007/s11104-11009-10085-z.

Wang, L., D'Odorico, P., Ries, L., Macko, S., 2010b. Patterns and implications of plant-soil 
$\delta^{13} \mathrm{C}$ and $\delta^{15} \mathrm{~N}$ values in African savanna ecosystems. Quaternary Research 73, 77-83.

Xiao, H., Li, X., Duan, Z., Li, T., Li, S., 2003a. Impact of evolution of plant-soil system on the water environment during the mobile dunes stabilization. Acta Pedologica Sinica 40, 809-814

Xiao, H., Li, X., Duan, Z., Li, T., Li, S., 2003b. Succession of plant-soil system in the process of mobile dunes stabilization. J Desert Res 23, 605-611.

Xiao, H., Cheng, G.D., Li, X.R., Song, Y.X., Wang, X.P. 2004. Ecohydrological change mechanism of a rainfed revegetation ecosystem at southeastern edge of Tengger desert, Northwest China. Sci. China Ser. D Earth Sci. 47, 71-77 (Supp). 
Table 1. Variations of vegetation, soil water and nutrient in the planted sand-binding vegetation at Shapotou.

The data were from Ma (2003) and Li et al., (2004).

\begin{tabular}{|c|c|c|c|c|c|c|c|c|}
\hline $\begin{array}{l}\text { Year of } \\
\text { Planting }\end{array}$ & $\begin{array}{l}\text { Vegetation } \\
\text { Cover }\end{array}$ & $\begin{array}{l}\text { Biomass } \\
\text { Density }\end{array}$ & $\begin{array}{c}\text { Clay } \\
\text { Content }\end{array}$ & $\begin{array}{c}\text { Crust } \\
\text { Thickness }\end{array}$ & $\begin{array}{c}\text { Soil } \\
\text { Moisture }\end{array}$ & \multicolumn{3}{|c|}{$\begin{array}{c}\text { Nutrient Content } \\
\left(\mathrm{g} \cdot \mathrm{kg}^{-1}\right)\end{array}$} \\
\hline (age) & $(\%)$ & $\left(\mathrm{kg} \cdot 100 \mathrm{~m}^{-2}\right)$ & (\%) & $(\mathrm{cm})$ & (\%) & $\mathrm{N}$ & $\mathrm{P}_{2} \mathrm{O}_{5}$ & $\begin{array}{r}\text { Organic } \\
\text { matter }\end{array}$ \\
\hline $1956(50)$ & 21.6 & 17.05 & 11.0 & 2.5 & 1.16 & 1.02 & 1.59 & 13.4 \\
\hline $1964(42)$ & 27.7 & 13.18 & 6.9 & 2.2 & 1.17 & 0.74 & 1.50 & 13.2 \\
\hline $1981(25)$ & 36.4 & 36.41 & 4.9 & 1.4 & 1.52 & 0.54 & 1.51 & 7.7 \\
\hline 1987 (19) & 30.0 & 39.74 & - & - & 2.03 & 0.38 & 1.04 & - \\
\hline
\end{tabular}

Table 2. Growing season meteorological conditions of the study site during the two sampling years.

\begin{tabular}{|c|c|c|c|c|c|c|c|}
\hline & \multicolumn{6}{|c|}{2004} & \multirow[b]{2}{*}{ Annual total } \\
\hline & May & June & July & August & September & Growing season & \\
\hline Mean temperature $\quad\left({ }^{\circ} \mathrm{C}\right)$ & 19.3 & 22.0 & 24.7 & 22.0 & 19.0 & 20.5 & / \\
\hline Rainfall (mm) & 2.9 & 25.5 & 26.4 & 48.7 & 2.1 & 107.1 & 116.2 \\
\hline \multirow[t]{3}{*}{ Relative humidity (\%) } & 28.9 & 41.0 & 44.3 & 64.0 & 46.7 & 41.5 & / \\
\hline & \multicolumn{6}{|c|}{2005} & \\
\hline & May & June & July & August & September & Growing season & Annual total \\
\hline Mean temperature $\left({ }^{\circ} \mathrm{C}\right)$ & 19.3 & 25.3 & 25.5 & 22.5 & 18.6 & 20.9 & I \\
\hline Rainfall (mm) & 15.6 & 3.5 & 14.3 & 10.7 & 15.9 & 61.3 & 74.9 \\
\hline Relative humidity (\%) & 34.0 & 28.0 & 44.0 & 53.0 & 52.0 & 37.8 & 1 \\
\hline
\end{tabular}


Table 3. Values of foliar $\delta^{15} \mathrm{~N}, \delta^{13} \mathrm{C}$, and nitrogen concentration ([N]) in Artemisia ordosica, Hedysarum scoparium, and Caragana korshinskii in China's Tengger Desert. Values of a parameter followed by different letters differ significantly $(P<0.05)$. Capital letters, boldfaced lowercase letters, and italic lowercase letters represent the differences in $\delta^{15} \mathrm{~N}, \delta^{13} \mathrm{C}$ and $[\mathrm{N}]$ among species. SE is the standard error, and $n$ is the sample size.

\begin{tabular}{|c|c|c|c|c|c|c|c|c|c|}
\hline & \multicolumn{3}{|c|}{ Artemisia ordosica } & \multicolumn{3}{|c|}{ Hedysarum scoparium } & \multicolumn{3}{|c|}{ Caragana korshinskii } \\
\hline & $\delta^{15} \mathrm{~N}(\%)$ & $\delta^{13} \mathrm{C}(\%)$ & {$[\mathrm{N}]\left(\mathrm{g} \cdot \mathrm{kg}^{-1}\right)$} & $\delta^{15} \mathrm{~N}(\%)$ & $\delta^{13} \mathrm{C}(\%)$ & {$[\mathrm{N}]\left(\mathrm{g} \cdot \mathrm{kg}^{-1}\right)$} & $\delta^{15} \mathrm{~N}(\%)$ & $\delta^{13} \mathrm{C}(\%)$ & {$[\mathrm{N}]\left(\mathrm{g} \cdot \mathrm{kg}^{-1}\right)$} \\
\hline Mean & $-3.1 \mathrm{~A}$ & $-24.4 a$ & $24.2 a$ & $-2.7 \mathrm{~B}$ & $-24.5 a$ & $22.7 a$ & $-1.5 \mathrm{C}$ & $-23.2 b$ & $16.1 b$ \\
\hline $\mathrm{SE}(n)$ & $0.10(131)$ & 0.08 (131) & $0.36(131)$ & 0.09 (135) & 0.09 (135) & $0.43(135)$ & $0.08(54)$ & $0.14(54)$ & $0.98(54)$ \\
\hline
\end{tabular}

Table 4. Values of foliar $\delta^{15} \mathrm{~N}, \delta^{13} \mathrm{C}$, and nitrogen concentration ([N]) in Artemisia ordosica, Hedysarum scoparium, and Caragana korshinskii in 2004 and 2005. SE is the standard error. Values of a parameter followed by different letters differ significantly $(P<0.05)$ between two sampling years. Difference represents the values in 2005 minus those in 2004.

\begin{tabular}{|c|c|c|c|c|c|c|c|c|c|c|}
\hline \multicolumn{2}{|c|}{ Species } & \multicolumn{3}{|c|}{ Artemisia ordosica } & \multicolumn{3}{|c|}{ Hedysarum scoparium } & \multicolumn{3}{|c|}{ Caragana korshinskii } \\
\hline & & $\delta^{15} \mathrm{~N}(\%)$ & $\delta^{13} \mathrm{C}(\%)$ & {$[\mathrm{N}]\left(\mathrm{g}^{\mathrm{kg}} \mathrm{kg}^{-1}\right)$} & $\delta^{15} \mathrm{~N}(\%)$ & $\delta^{13} \mathrm{C}(\%)$ & {$[\mathrm{N}]\left(\mathrm{g} \cdot \mathrm{kg}^{-1}\right)$} & $\delta^{15} \mathrm{~N}(\%)$ & $\delta^{13} \mathrm{C}(\%)$ & {$[\mathrm{N}]\left(\mathrm{g}^{\mathrm{kg}} \mathrm{kg}^{-1}\right)$} \\
\hline 2004 & Mean & $-2.8 \mathrm{~A}$ & $-25.0 \mathrm{~A}$ & $23.4 \mathrm{~A}$ & $-3.0 \mathrm{~A}$ & $-25.2 \mathrm{~A}$ & $22.1 \mathrm{~A}$ & $-1.7 \mathrm{~A}$ & $-24.3 \mathrm{~A}$ & $23.6 \mathrm{~A}$ \\
\hline (dry) & SE & 0.2 & 0.1 & 0.5 & 0.1 & 0.1 & 0.4 & 0.1 & 0.1 & 0.5 \\
\hline 2005 & Mean & $-3.3 \mathrm{~A}$ & $-24.0 \mathrm{~B}$ & $24.9 \mathrm{~A}$ & $-2.4 \mathrm{~A}$ & $-24.1 \mathrm{~B}$ & $23.2 \mathrm{~A}$ & $-1.4 \mathrm{~A}$ & $-22.5 \mathrm{~B}$ & $9.8 \mathrm{~B}$ \\
\hline (extremely dry) & $\mathrm{SE}$ & 0.1 & 0.1 & 0.5 & 0.1 & 0.1 & 0.7 & 0.1 & 0.1 & 0.6 \\
\hline Difference & & -0.5 & 1.0 & 1.5 & 0.6 & 1.1 & 1.1 & 0.3 & 1.8 & -13.7 \\
\hline
\end{tabular}


Table 5. Correlation coefficients of the foliar [N] $\left(\mathrm{g} \cdot \mathrm{kg}^{-1}\right), \delta^{13} \mathrm{C}(\%)$ and $\delta^{15} \mathrm{~N}(\%)$ in Artemisia ordosica, Hedysarum scoparium and Caragana korshinskii in 2004 and 2005.

\begin{tabular}{|c|c|c|c|c|c|c|c|}
\hline \multicolumn{8}{|c|}{ Artemisia ordosica } \\
\hline & & \multicolumn{3}{|c|}{2004} & \multicolumn{3}{|c|}{2005} \\
\hline & & $\delta^{13} \mathrm{C}$ & $\delta^{15} \mathrm{~N}$ & {$[\mathrm{~N}]$} & $\delta^{13} \mathrm{C}$ & $\delta^{15} \mathrm{~N}$ & {$[\mathrm{~N}]$} \\
\hline & $\delta^{13} \mathrm{C}$ & 1.0 & & & & & \\
\hline \multirow[t]{3}{*}{2004} & $\delta^{15} \mathrm{~N}$ & 0.21 & 1.0 & & & & \\
\hline & {$[\mathrm{N}]$} & 0.25 & $0.41^{* * *}$ & 1.0 & & & \\
\hline & $\delta^{13} \mathrm{C}$ & $0.70 * * *$ & -0.003 & 0.02 & 1.0 & & \\
\hline \multirow[t]{5}{*}{2005} & $\delta^{15} \mathrm{~N}$ & 0.11 & $0.54 * * *$ & 0.24 & 0.03 & 1.0 & \\
\hline & {$[\mathrm{N}]$} & 0.15 & 0.08 & 0.25 & 0.16 & $0.28 * *$ & 1.0 \\
\hline & & \multicolumn{6}{|c|}{ Hedysarum scoparium } \\
\hline & & \multicolumn{3}{|c|}{2004} & \multicolumn{3}{|c|}{2005} \\
\hline & & $\delta^{13} \mathrm{C}$ & $\delta^{15} \mathrm{~N}$ & {$[\mathrm{~N}]$} & $\delta^{13} \mathrm{C}$ & $\delta^{15} \mathrm{~N}$ & {$[\mathrm{~N}]$} \\
\hline & $\delta^{13} \mathrm{C}$ & 1.0 & & & & & \\
\hline \multirow[t]{3}{*}{2004} & $\delta^{15} \mathrm{~N}$ & $0.31 *$ & 1.0 & & & & \\
\hline & {$[\mathrm{N}]$} & -0.19 & 0.10 & 1.0 & & & \\
\hline & $\delta^{13} \mathrm{C}$ & $0.47 * *$ & 0.08 & 0.13 & 1.0 & & \\
\hline \multirow[t]{2}{*}{2005} & $\delta^{15} \mathrm{~N}$ & 0.10 & 0.20 & -0.03 & $0.38 * *$ & 1.0 & \\
\hline & {$[\mathrm{N}]$} & 0.006 & 0.13 & $0.53 * *$ & $0.39 * * *$ & 0.22 & 1.0 \\
\hline \multicolumn{8}{|c|}{ Caragana korshinskii } \\
\hline & & \multicolumn{3}{|c|}{2004} & \multicolumn{3}{|c|}{2005} \\
\hline & & $\delta^{13} \mathrm{C}$ & $\delta^{15} \mathrm{~N}$ & {$[\mathrm{~N}]$} & $\delta^{13} \mathrm{C}$ & $\delta^{15} \mathrm{~N}$ & {$[\mathrm{~N}]$} \\
\hline \multirow{3}{*}{2004} & $\delta^{13} \mathrm{C}$ & 1.0 & & & & & \\
\hline & $\delta^{15} \mathrm{~N}$ & $0.74 * * *$ & 1.0 & & & & \\
\hline & {$[\mathrm{N}]$} & 0.17 & 0.20 & 1.0 & & & \\
\hline \multirow{3}{*}{2005} & $\delta^{13} \mathrm{C}$ & $0.58 * *$ & $0.57 * *$ & 0.21 & 1.0 & & \\
\hline & $\delta^{15} \mathrm{~N}$ & $0.64^{* *}$ & $0.60 * *$ & 0.32 & $0.77^{* * *}$ & 1.0 & \\
\hline & {$[\mathrm{N}]$} & 0.36 & 0.12 & $0.54 * *$ & $0.49 * *$ & 0.29 & 1.0 \\
\hline
\end{tabular}

Note: ${ }^{*} \mathrm{p}<0.05, \quad{ }^{* *} \mathrm{p}<0.01,{ }^{* * *} \mathrm{p}<0.001$ 
Figure 1. Study area and sampling sites in the south-eastern margin of the Tengger Desert (a, b, c and d indicate sand-fixing zone planted in 1956, 1964, 1981 and 1987 without irrigation and fertilization).

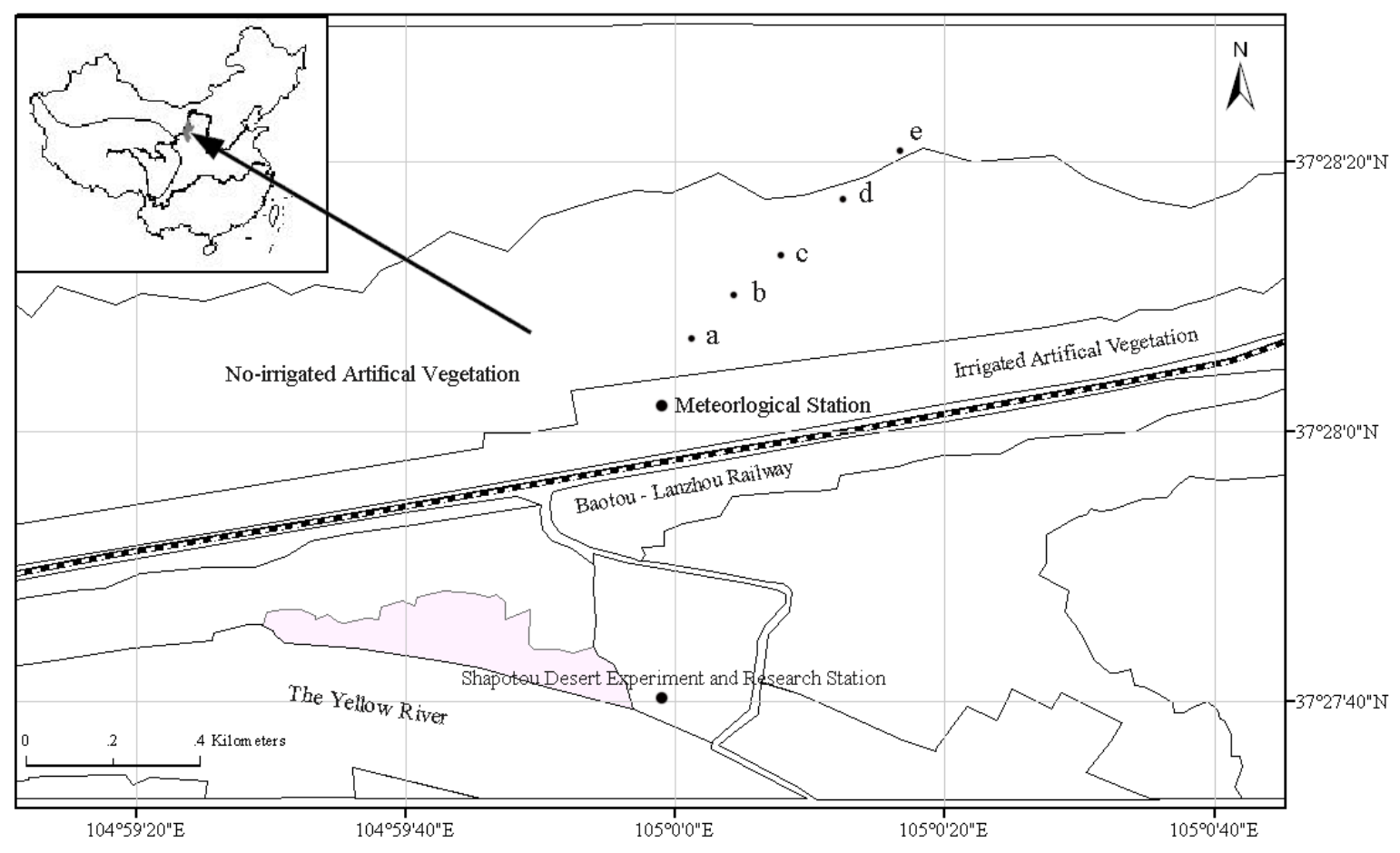

Figure 1 
Figure 2. Effects of successional age on foliar $\delta^{15} \mathrm{~N}, \delta^{13} \mathrm{C}$ and $[\mathrm{N}]$ in Artemisia ordosica, Hedysarum scoparium and Caragana korshinskii in the Tengger Desert. Different lowercase and italic lowercase letters indicate significant differences among the successional age in 2004 and 2005, respectively.

The error bars represent standard deviations.

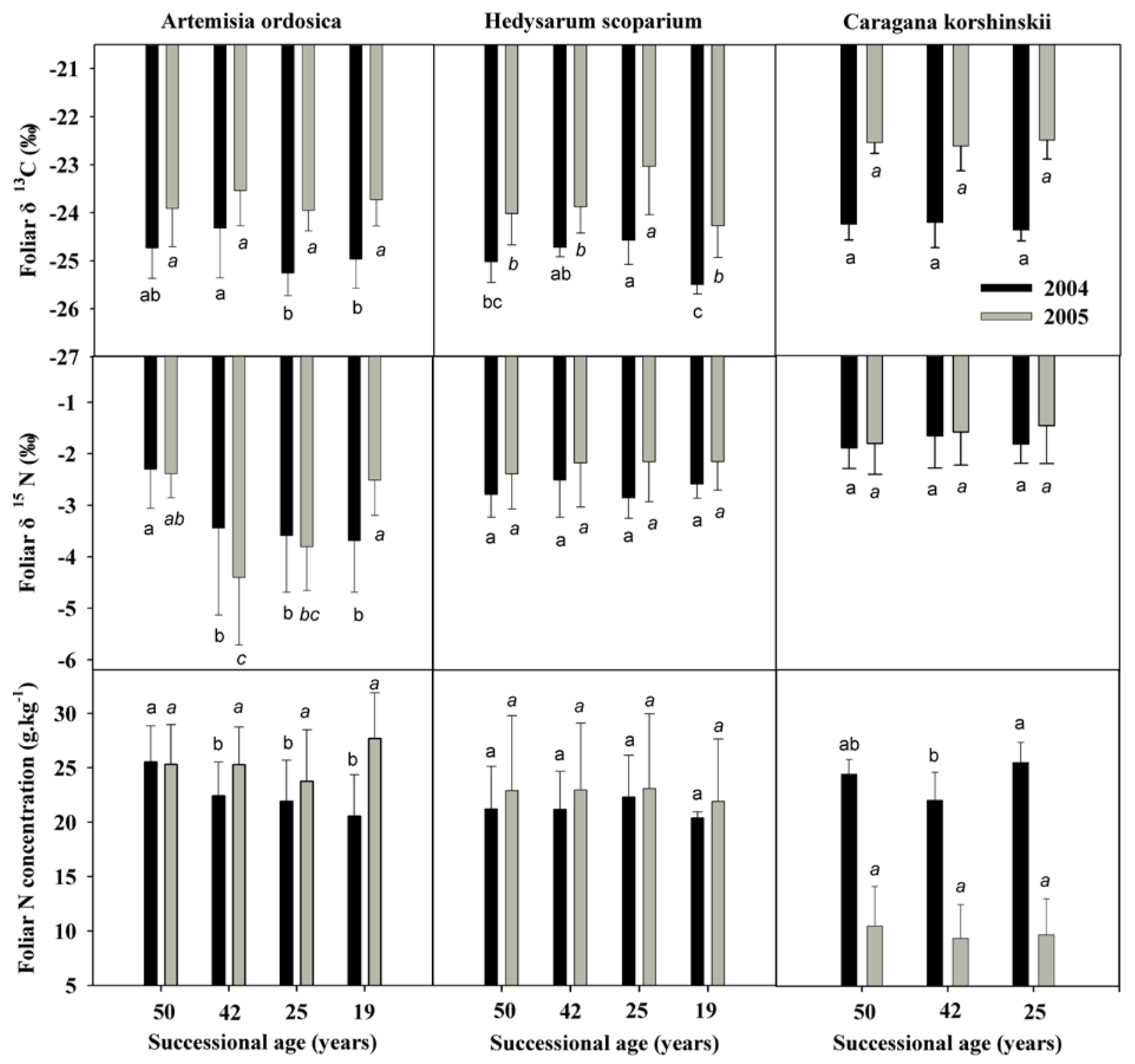

Figure 2 
Figure 3. The effects of seasonality on the foliar $\delta^{15} \mathrm{~N}, \delta^{13} \mathrm{C}$ and [N] in Artemisia ordosica (a, b and c), Hedysarum scoparium (d, e and f) and Caragana korshinskii (g, h and i) in 2004 and 2005. Different boldfaced lowercase letters indicate there are significant differences among the seasons in 2004, and different italic lowercase letters indicate there are significant differences among the seasons in 2005. $*(\mathrm{p}<0.05), * *(\mathrm{p}<0.01)$ and $* * *(\mathrm{p}<0.001)$ indicate that there are significant differences between two years.

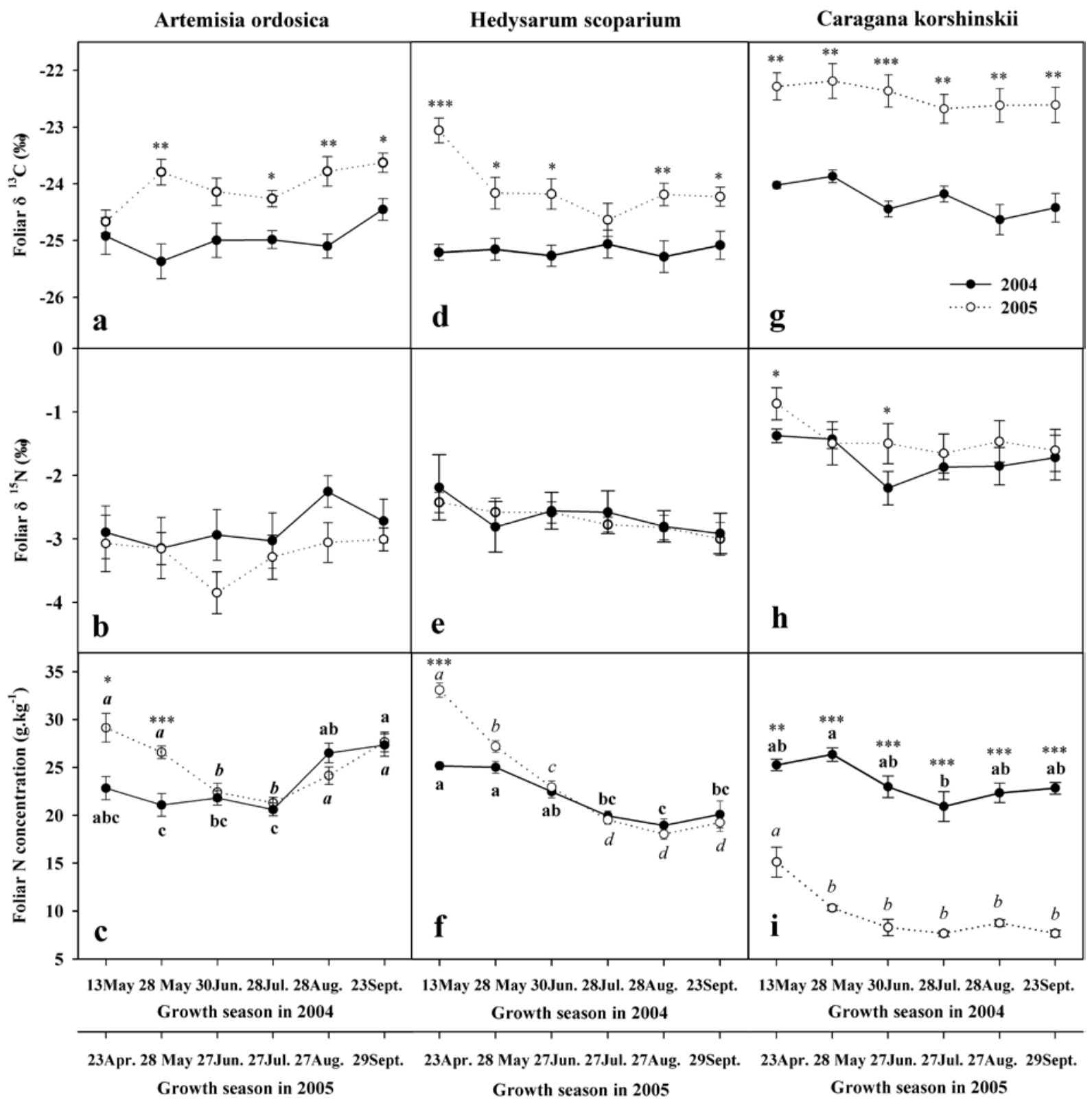

\section{Figure 3.}


Figure 4. The monthly precipitation (the bars on the top) and soil water capacity of top three meters in the planted site (the solid line) and sand dues (the dashed line). The x-axis represents the number of months after the plantation of sand-binding vegetation. The thicker solid lines are the six-month running averages of the vegetated and sand dune data. The linear regression equations and average soil water capacity values of three distinct periods were also reported for the vegetated site. This figure is modified based on the data from Xiao et al. (2004).

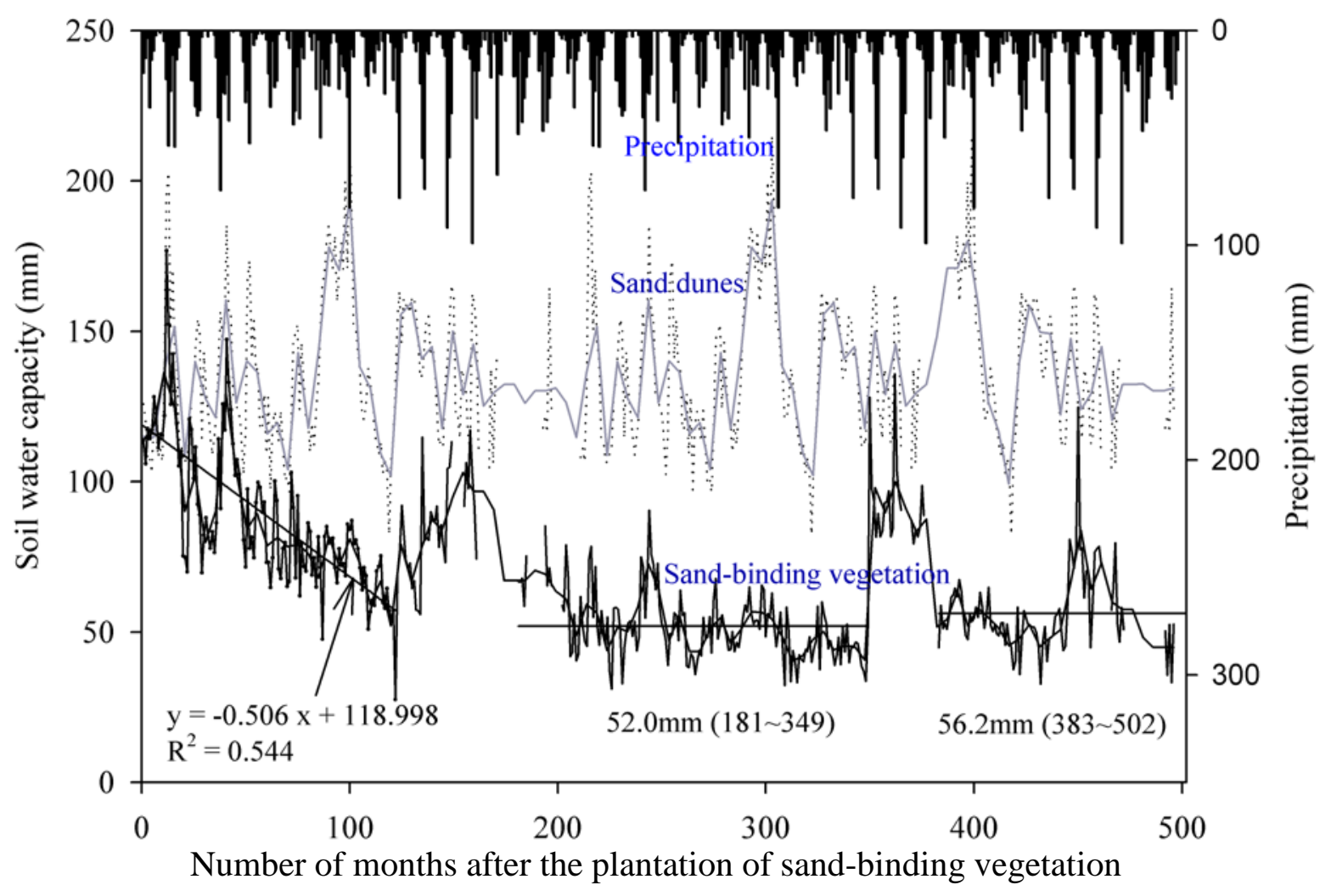

Figure 4. 
